\title{
Income Tax Noncompliance in Nigeria and the Moderating Effect of Public Governance Quality: A Suggested Framework
}

\section{Mohammed Abdullahi Umar}

\author{
Department of Accounting, Kogi State University, Nigeria; philosophiaconsult@yahoo.com
}

Chek Derashid

Associate Professor, School of Accounting, Universiti Utara, Sintok, Malaysia chek@uum.edu.my

\section{Idawati Binti Ibrahim}

Senior Lecturer, School of Accounting, Universiti Utara, Sintok, Malaysia idawati@uum.edu.my

\author{
Doi:10.5901/mjss.2016.v7n6p339
}

\begin{abstract}
Income tax noncompliance is a huge problem in Nigeria making the country one of the lowest income tax countries in the world based on percentage of GDP. The study reviews and integrate previous research and causes of noncompliance were identified - Socio economic condition, tax knowledge, perceived audit probability and prevailing social norm . However, as acknowledged by researchers, over fifty years of research on noncompliance is yet to produce a formula that can solve noncompliance problems applicable to all jurisdictions hence the need to develop country-specific models. Given that Nigeria has one of the largest informal sectors in the world, this study adds perceived attractiveness of the informal sector as a factor and reconstructs public governance quality as moderator of other factors. The study argues that the above factors are present in all countries of the world; if they are worse in Nigeria, then a moderator could be the problem and public governance quality is plausible given Nigeria's poor record. Facts from previous research support this position. It is recommended that Nigerian government urgently improve on public governance to reduce the size of the informal sector and mitigate the effects of the other factors. Further research is needed to statistically analyse the suggested framework.
\end{abstract}

Keywords: Income tax noncompliance, Public governance quality, Social norm, Tax knowledge, Audit probability.

\section{Introduction}

Nigeria is classified as a middle income country. It has witnessed a consistently high growth rate of over $6 \%$ over the last decade. (OECD, 2014). The GDP of the country was recently (2014) rebased to about $\$ 510$ making it the largest economy in Africa, a position previously held by South Africa. However, within this impressive economic statistics, the citizens live in one of the worst socio-economic conditions in the world. According to OECD 2014, Nigeria has the highest number of poor people in the world, after India and China, with about 58 million out of a population of 158 million living in extreme poverty. Furthermore, OECD (2014) stated that 100 women die each day as a result of pregnancy and childbirth related conditions while over 2000 children below the age of five die every day from diseases that can be prevented. The report stated that about 8.5 million children do not attend school in Nigeria positing that the figure is the highest in the world.

The above statistics is a striking paradox of impressive economic statistics with grim socio-economic living conditions. Why have the Nigerian government not been able to raise adequate revenue to provide minimally acceptable education, health and socio-economic infrastructure? This study argues that a possible reason for the inability of government to provide adequate public infrastructure and to reduce the yawning rich-poor dichotomy is the inability to raise adequate tax. According to Alabede (2001), the fund government utilizes to prosecute its numerous programs are acquired through tax and non-tax revenues but Bruautigham (2002) stated that taxation is the major source of government revenue. Liman (2009) posits that tax is the most significant and the most reliable source of government revenue. Wang (2001) position is in line with Brautigham, and Liman. In a study of state building in China between 1949 
and 1953, he opined that the basic aspect of state building is extracting resources from the state. He cited Almond \& Powell (1966) and Brawn 1975, all supporting the view that revenue raising ability is at the core of modern state building. Bird, Martinez-vazquez \& Toggler (2007) stated that developing countries would need to invest on public infrastructure on education, health services and others and to do this, they need to come up with more tax effort.

Kaldor (1963) is of the opinion that the importance of tax in yielding public revenue is more pronounced in developing countries given the abysmal state of their public infrastructure. He stated that while developed countries raise average of, $25-30 \%$ of their GDPs as tax, developing countries, including Nigeria, raise between $8-15 \%$. He agreed with the position that part of the blame is government's inability to tax which, he argues, also fuels income inequality in these countries. Kaldor maintained that taxes in developing countries tend to be regressive thus failing to tax the wealthy. This implies that, apart from not mobilizing enough revenue for government programs, inequality is made worse.

Furthermore, Kaldor's position provides a clue to Nigeria's paradox of poverty amidst plenty. The country has the highest number of poor people in the world after China and India (OECD, 2014) because the government could not transfer resources from the rich by way of taxation. The government also cannot provide adequate public goods because it cannot mobilize adequate resources through taxing income in a $\$ 510$ billion economy - the biggest in Africa. But having the biggest GDP in Africa does not translate to tax performance for Nigeria when measured against other Africa countries. Volkerink (2009) compared fourteen Africa countries and found out that Nigeria came third to the last in terms of income tax to GDP ratio. on the global stage, the share of income tax as a percentage of total tax for the OECD countries in 2012 were: Australia, 58.1\%, Denmark, 69.1\%, Germany, 30.4\%, New Zealand 55.5\%, Norway, 48.2\%, UK $35.6 \%$ and USA $47.9 \%$ (OECD,2014 A). In contrast Nigeria has performed below average in income tax generation. Alabede (2012) noted that the income tax ratio was $1.6 \%$ in 2003 but by 2008 , it fell to $1.4 \%$. There is no evidence that this situation has improved since then.

The poor performance of income tax in Nigeria seems to have affected the general tax performance. Oyedele (2014) asserted that based on Nigeria's 2013 rebased GDP, Nigeria's non-oil tax to GDP ratio is one of the lowest in the world. cobham (2014) agree with this position. Despite consistent high economic growth over a decade (OECD, 2014B) and the GDP now rated as one of the highest in the world and highest in Africa, why has Nigeria not been able to translate these economic figures into tax revenue urgently needed for development? Jenkins, Kuo and Shukla (2000) stated that the amount of tax revenue a government can collect depend on these variables: Tax base, tax rate, administrative efficiency and the compliance rate. This position is in line with the mainstream philosophy of tax scholars. Examining these variables; this study argues that with the current high level of GDP, which is also dominated by the service sector, there exists adequate tax base to significantly increase the current level of income tax revenue in Nigeria. The next variable is the tax rate. This study argues that it is not a significant problem of raising tax revenue in Nigeria given that there are no empirical findings to the contrary and the fact that Nigeria do not operate a tax rate significantly different from the countries that perform better in tax revenue generation. On administrative efficiency, the revenue agency of Nigeria has undergone significant reform in over the past decade (FIRS, 2012).

Thus, we are left with the compliance rate. This study argues that noncompliance could possibly explain the dismal income tax statistics of Nigeria. This position can be supported with research findings that measured Nigeria's informal economy. Malaolu and Ogbuabor (2013) found that, since 1970, yearly size of the informal economy falls within 53.6\% $77.2 \%$ of GDP which translate to $64.6 \%$ on average. The study also isolates the extreme case of 2010 when the informal economy was about three-quarter of the economy. Philip consulting (2011) strengthened this position. The study asserted that the informal economy in Nigeria is a huge one harbouring about 17 million business enterprises with this level of the informal economy noncompliance would be a problem for tax revenue generation in Nigeria.

Given the importance of tax revenue to economic development, a great deal of research work has been carried out over the past decades in the efforts to tackle the menace of noncompliance and also to understand the opposite side of the same coin - why people comply. Since the pioneering work of Allingham \& Sandino (1972) which introduced the economics of crime approach based the on Becker's (1968) deterrence theory, many theories and models have been developed, citing inadequacy of the A.S model. Some of these newer models were expansion of the earlier models while some took radically different insights into the tax evasion /compliance quagmire. Homan (1974); Bandura (1997); Alm, Martinez _ Vazquez and Togler (2010); Schenellenbach (2010); Field and Frey (2010); Kichler, Muel, Ingrid and Wahl (2010) and many others have contributed to perspectives on the subject of tax evasion/ compliance.

However, while some countries (especially developed ones) have relatively succeeded in maintaining tax- effective economies, many developing countries are unable to raise adequate tax revenue. As pointed out earlier, Nigeria's case has been acknowledged as outstandingly worrisome. The objective of this study is to explain the low tax compliance in Nigeria especially the role of government in this problem. This study intends to contribute to the growing tax evasion/ compliance knowledge by proposing a framework that could explain the problem in Nigeria. Setting the motivation for this 
study is Bird (2013) who lamented that there have been over fifty years of active research in the area of taxation which has not yet resolved the issues. He posited that it is difficult to find any model that can solve all the problems of tax noncompliance in all countries and that developing countries display an array and a wide range of tax compliance levels which are reflective of their respective tax administrations, attitudes towards their governments amidst other conditions. In Bird's opinion, several years of tax research has not produced "a magical fiscal medicine" that can solve all the problems. He thus advocated for home-grown solutions based on peculiarities facing different countries and government. This study thus responds to Bird's call and seeks to understand the peculiarities of Nigeria income tax non-compliance and factors responsible

\section{Methodology}

The study was designed as a conceptual and integrative literature research in response to Bird's (2013) assertion that over fifty years of noncompliance research has not produced a generally applicable solution to countries' tax problems. He advocated the search for country-specific solutions. Given the enormity of research by scholars over the last fifty years, the remarkable progress made by many countries in generating income tax and the below average performance of Nigeria, this study decides to search for a conceptual framework that can possibly explain the Nigerian income tax noncompliance case in line with Walliman (2011). The study conducted extensive literature review of scholarly articles (empirical and theoretical) using EBSCO Elsevier, Emerald, SAGE journals and Google search engines. The search and review revealed numerous factors found to have contributed to income tax noncompliance over several years. Based on Silverman (2005), variables essential and applicable to the Nigerian context were picked. Alabede et al (2011) advocated the search for a moderating variable when noncompliance behaviour are extreme like the case in Nigeria. Baron \& Kenny (1986) described a moderator as a variable that influences the direction and/or strength of the correlation between a dependent and an independent variable. The literature reviews for this study suggests public governance quality as a possible moderator. To the best of the researcher's knowledge, this variable have been extensively discussed among Nigerian tax scholars but has never been tested as a possible moderator of other factors affecting income tax noncompliance in Nigeria. Reconstructing the noncompliance variables by testing public governance quality as a moderator is a novel contribution to tax noncompliance knowledge in Nigeria. Picking on public governance quality in Nigeria is also justified by the low rating of the country in major international measurement index like the World Governance Index (WGI), Transparency International Corruption Perception Index (PCl) and Mo Ibrahim African Governance Index.

This study favours the conceptual methodology rather than the empirical method because it is a novel concept in trying to explain the Nigerian income tax noncompliance context. Fawcett, Hazen, Miller, Overstreet \& Waller (2014) justified the use of conceptual methodology in trying out a new scheme: "Conceptual research helps us to see the world and decision making phenomena through new lenses, enabling us to find new trailheads for existing and emerging problem-solving quests. Once these research opportunities are identified, subsequent empirical research moves us further down the knowledge-discovery path." (P.2).

\section{Public Governance Quality}

The social contract theory is a precursor of modern government. Wikipedia cited early philosophers (Grotius, 1625; Hobbes, 1651; Pufendorf, 1673; Locke, 1689 \& Roseau, 1762) as advocates of this theory which envisaged the surrender of individual sovereignty to the state in exchange for collective protection of lives and property to maintenance of public utilities whose costs may be beyond private individuals. Musgrave (1959) and Reinert (1999) focused on the economic roles of government in addition to the traditional protection of lives, property and maintenance of law. These economic roles of government in addition to the traditional roles include allocation and distribution of economic resource, stabilization of the economy, providing income redistribution and ensuring economic growth. Thus, the functions of modern government are clear, unambiguous and well spelt-out.

However, records show that governments of various countries have performed differently on their ability to translate public governance to public goods and services. The quality of public governance is partly responsible for some countries with huge natural resources wallowing in extreme poverty while others with meagre natural resources transformed into high income nations (Sachs \& Warner, 1997).

International organizations are concerned about the quality of public governance. This is understandable since they grant developmental aids and loans to countries and they also grapple with refugees and humanitarian crises arising from bad governance. Buduru \& Paul (2010), cited some of the indicators developed by international organizations to 
measure the quality of public governance -World Bank, Transparency International, Freedom House and others. Mcfersor (2009), however, posits that the world wide governance indictor (WGI) developed by the World Bank is the most elaborate. It has been in used since 1996. The WGI indicators are: Voice and Accountability, Political stability and absence of violence, Government effectiveness Regulatory quality, Rule of law and Control of corruption.

Some scholars have argued that these governance indicators are inadequate and unreliable while others posit that they are flawed when used against country-specific governance reality ( Quist, 2014). While it can be argued that these indicators are not perfect, they have been widely adopted internationally and they are being improved. Some of the theories underpinning the study of tax compliance have implications for the integration of public governance quality into their context.

Good public governance quality enhances tax compliance by citizens and ultimately leads to availability of more funds for public programs. Conversely, poor public governance quality impoverish and alienate citizens who also react by failing to pay tax thereby leading to inadequate funding for public programs. This study thus argues strongly that public governance quality is a key component in modelling tax compliance behaviour. This position is also justified by Alm, Martinez-Vazquez and Torgler (2010:174): "Tax evasion is part of a more general syndrome of corruption, impotent legal system, shaky economies, and especially, inefficient governments that fail to provide essential services."

\section{Factors Influencing Tax Noncompliance and the Moderating Role of Public Governance Quality}

\subsection{Social Norm}

Posner \& Rasmussen, (1999) sees social norms as social rules by which members of a society self-regulate, think or act irrespective of government laws or sanctions. The violation of these social rules according to Posner and Rasmussen can lead to guilt and shame. Helbing, Wenjian, Karl-Dieter and Rawhut( 2014) describe social norms as one of the most significant factors that define social life. Posner (1997) describe social norms as a set of rules that are neither introduced by acts of parliament or constitutions nor enforced by law-enforcement agencies. What all these positions connote is that, within a society, certain behaviours are considered the right thing to do so people conform. Other ways of behaving are frowned at and people likewise desist from such actions. Doing what the generality of societal members approve will be rewarded with approval and acceptance among members of the society as doing things otherwise will attract rejection and sanctions by societal members. However, social norms vary from one society to another. What constitute a blasphemy or criminality in one society may just be a normal occurrence in another society.

What has social norm got to do with income tax compliance? Martin (2012) said people act based on what others around them are doing. Could this translate to the fact that people will pay income tax when they see others paying? This study argues that this is likely. Martin (2012) analysed the result of series of letters sent by the British tax authorities to defaulters reminding them to pay up their tax liabilities. In Nigeria, where it has already been argued that income tax performance is very low, noncompliance is almost assuming the status of a social norm.

\subsubsection{The Moderating Role of Public Governance Quality on the Relationship between Social Norm and Tax Noncompliance}

Income tax noncompliance is not desirable by any government as the ability of government to fund its programs largely depends on how much tax revenue it can mobilize. It then assumes a paradoxical dimension when the same government that needs tax revenue is suggested to be contributing to noncompliance by virtue of the quality of public governance it is providing. How does government in Nigeria moderate the effect of social norm on income tax noncompliance? Posner and Rasmussen (1999) posits that norms can be created, can change and can be destroyed. It appears successive governments has, through bad quality governance, created a new social norm of income tax noncompliance and destroyed a hitherto tax compliance norm. Research studies are unanimous on the fact that Nigerians had a vibrant tax paying culture prior to the oil boom which diverted government attention from income tax (Nwokeji, 2007; Olajide, Akinlade \& Tijani, 2012; Ariyo, 1997; Budina \&Wijnbergen, 2008). The rapid decline in income tax compliance in Nigeria after the oil boom revenues started flowing into government coffers can be arguably attributed to governance failure which has created and sustained a social norm of income tax noncompliance. Okoye, Akenbor and obara (2012) strengthened this position. They stated that despite the existence of laws stipulating penalties for noncompliance, the laws are not implemented and evaders are not often prosecuted. Perhaps this send a subtle signal across the society that income tax noncompliance is a tolerable offence. In such a situation, even those who would wish to comply may not bother. Bird (2008) as cited by okoye et al, corroborates this position by saying a country's path to sustainable growth would be blocked if tax evaders go scot free. 


\subsection{Tax Knowledge/Education}

Hofmann, Hoelzl and kirchler (2008) described tax knowledge as a significant factor that influenced tax compliance behaviour. They cited Mckerchar, (2001) as saying tax laws are complex, highly abstract and contains technical jargons. They also cited Lewis (1982) as saying, by the end of the 1970s, comprehending tax issues in Britain required about 13years of education while 12.5years is considered the benchmark in the USA and Australia's estimate was 17years. Given the low level of literacy in Nigeria and other developing countries, it is doubtful whether a large proportion of prospective income tax payers meet this educational requirement. Saad (2013) is of the view that the introduction of the self-assessment system globally further underscores the need for educated tax payers. He posited that since income tax payers are expected to compute their tax liabilities and file returns, they must possess minimum educational skills.

Alabede (2014) studied the effect of education on tax compliance. He cited Kornhauser (2007), Groenland \& Veldhoven (1983) and Song \& Yarbrough (1976) as previous researchers who have found the effect of education on tax compliance to be positive. While level of education could be attributed to years of formal education and earned certificates, tax knowledge involves passing information and creating awareness about tax policies and programs of government. Olowookere \& Fashina (2013) studied tax-payers education in Nigeria. They cited Azubike (2009) saying the Nigeria tax administrative system is encumbered by a communication gap between tax payers and authorities. The same study cited Fischer (1982) which reviewed literature on compliance and found out that educated tax payers appear to cooperate more with tax authorities since they understand the necessity for raising revenue to finance public services.

\subsubsection{The Moderating Role of Public Governance Quality on the Relationship Between Tax Knowledge/Education and Tax Noncompliance}

Can public governance quality play a role in tax payers' education and tax knowledge/awareness as they influence tax compliance? Onuba (2011) cited in Oloowokere \& Fashina (2013) stated that tax-payers perception that government was unaccountable to them poses a problem to the tax system. This suggest that government's failure to put up a deliberate policy of educating and informing tax payers is a moderator of the effect of ignorance on tax noncompliance.

\subsection{Perceived Audit Probability/ Effectiveness}

Tax audit is crucial to effective tax administration. Before alternative models for explaining the complexities of tax compliance evolved, the classical study on tax compliance by Alinghan and Sandmo (1972) utilized the economics-ofcrime model of Becker (1968). This approach stated that the individual tax payer is involved in a rational economic decision while contemplating paying tax. He weighs the risky prospect of being caught with attendant penalty and the favourable prospect of escaping undetected thereby making economic gain. According to Alm, Martinez-Vazquez \& Torgler (2010), this approach projects audit as a deterrent to possible noncompliance since audit portends the danger of being caught.

Many tax compliance researchers have since put forward alternatives compliance models to explain tax compliance behaviour (Weigel, Hessing \& Elfer, 1978; Lewis, 1982; Fischer, Watick \&Mark,1992 etc.). A common thread that runs through these alternative models is that the economics of crime approach, with its emphasis on audit, is not enough to explain the dynamics of tax compliance. Alm et al (2010) for instance, stated that the number of tax returns subjected to audit in most countries is considerably less than 1 per cent of all returns. Yet, in America, the about 83percent compliance could not have been explained by the disproportionate amount of audit. However, despite reaching a consensus that audit alone does not account for a large number of tax compliance, researchers have not downplayed the role of audit in ensuring compliance. Devos (2014) stated that deterrence, tax equity/fairness and tax morals are the predominant factors that scholars have attributed to compliance decisions-deterrence is linked to audit.

\subsubsection{The Moderating Effect of Public Governance Quality on the Relationship Between Audit Probability/Effectiveness and Tax Noncompliance}

While it is the responsibility of the tax authorities to audit tax payers and enforce sanctions on noncompliance, the quality of public governance would determine the political support given to the tax authorities. Devos (2014) as stated earlier, identified deterrence, tax equity/fairness and tax morals as the predominant factors that determines compliance decisions. This study argues that these factors are largely shaped by public governance. Tax payers would be deterred if audit rate is frequent and effective. Tax equity/fairness implies that the tax authorities acting under the political leadership do not give preferential treatment to some tax payers to the detriment of others. It appears this may not be the case in 
Nigeria. Igbo \& Oyadonghan (2013) posits that tax compliance is neither audited nor enforced in Nigeria and contend that if sanctions are the determinants of tax compliance alone, people would as well not pay tax. This is a pointer to the low level of audit and enforcement in Nigeria.

A contrasting overview of the American tax audit system supports the argument that public governance quality play a role in the use of Audit in influencing tax compliance. IRS (2004) as cited in Bloomquist (2004) reported that 849,000 audits on individual income tax returns discovered and demanded for $\$ 4.6$ billion additional tax in the financial year end, 2003. This translates to $\$ 5,400$ average. This is a remarkable effort from a country that gives priority to income tax compliance. The USA government is reputed for its tough stance against income tax noncompliance and treating it as a serious criminal offence. Blank (2014) reported a recent Supreme Court case, Kawashima v. Holder, where some individuals found guilty of tax fraud may be subjected to deportation from the US. It can thus be argued that the extent to which Audit or its effectiveness influence tax compliance decisions will be moderated by the public governance quality in Nigeria.

\subsection{Socio-economic Conditions}

Alabede, Ariffin and Idris (2011) drew attention to the role of financial condition as a factor influencing tax compliance in Nigeria. They cited Mathew and Zajac (1990); Cron and Slocum, (1995); Doran, Stone, Brief and George, (1995) and Brett et al (1995) as studies that have earlier discovered that financial condition affects commitment and performance. It is implied from Alabede et al (2011) that these earlier studies were not on tax compliance but they adopted the financial condition construct from these studies to test on their tax compliance study in Nigeria. The study cited Brett et al (1995), Claiming that the moderating effect of personal financial condition as it affects tax compliance is more pronounced in developing countries generally and Nigeria where poverty is pervasive coupled with high family responsibilities. Besley and Persson (2014) demonstrated the positive correlation between countries income per capita and amount of tax they collect positing that developing countries collect little income tax because of their relatively low income per capita and the preponderance of small businesses in the informal sector. They argued that a key motive for these informal activities is to evade tax. This postulation aptly describes the Nigerian scenario. Why do low income earners avoid contributing to the state's common pool? What role does their financial condition play in tax noncompliance decisions of income earners in a poverty-stricken nation like Nigeria and how does social circumstances blend with economic factors to foster the socioeconomic conditions fuelling tax noncompliance in Nigeria? These are relevant questions that the socio-economic condition variable seeks to answer.

While Alabede et al (2011) used financial condition as a variable in determining tax noncompliance in Nigeria, this study proposed socio-economic condition arguing that some social metrics are behind the financial conditions that affect people. This construct is also used by the National Bureau of Statistics (NBS, 2014). The social factors that contribute to worsening financial conditions in Nigeria are inadequate government expenditure on healthcare thereby forcing income earners to provide their own healthcare at very exorbitant and inefficient rate (Eneji, Juliana \& Onabe, 2013). Likewise, Oseni (2012) posits that the funding of education in Nigeria is far below the benchmark recommended by UNESCO thereby creating a situation where income earners spend so much in providing education to their dependants. NBS (2014) puts the unemployment rate for 2011 at about 24\% projecting an increase to $30 \%$ in 2014. This large population of unemployed people coupled with a large population of rural dwellers all depend on the middle class urban dwellers for sustenance based on the extended family system practiced in Nigeria. With this pressure on the income earners, income tax noncompliance becomes rampant.

\subsubsection{The Moderating Role of Public Governance Quality on the Relationship Between Socioeconomic Condition and Tax Noncompliance}

The proponents of capitalism and the role of government were considerate enough by providing a cushion for vulnerable members of the society. Musgrave (1959) asserted that the economic roles of government include allocation, distribution and stabilization. Reinert (1999) is of the view that government is a provider of institutions, provider of a level playing field, income distributor and enabler of economic growth. It can be inferred from the above that not only does citizens' safety lies with their governments (Smith 1776) but their ultimate economic prosperity can result from acts of omission or commission of their governments. Specifically, citizens' prosperity will depend on whether governments distribute and allocate economic resources optimally and whether or not governments put up policies that ensure income redistribution.

This study argues that capacity of citizens to comply with income tax will depend on whether they generate incomes enough to sustain their basic needs and whether there is effective governance to channel whatever they pay as 
tax to overall public goods. Studies have shown that countries' economic performance do not always correlate with abundance of resources but with sound economic policies alongside quality public governance (Sachs \& Warner, 1997). In the Nigerian case, consistent high growth has been recorded in the economy within the last ten years and a current rebasing of the GDP(2013) has made the country the largest economy in Africa and among the top thirty in the world (EY, 2014). However, over 58 million Nigerian citizens are believed to be below the poverty line (OECD,2014). This has prompted many scholars to describe the Nigerian case as a paradox of poverty amidst plenty. This study argues that public governance quality could be the cause of a growing economy which also continues to harbour increasingly impoverished citizens. This is based on Musgrave's (1959) view of economic role of government as allocator, distributor and stabilizer. Added to this is the high level of corruption (Cowen \& Tabarrok). High level of corruption implies that public fund is diverted to the private use of privilege elites. This leads to stagnating income growth among generality of citizens thereby worsening the socio-economic conditions that impedes tax compliance.

\subsection{Informal Economy}

The shadow economy exists all over the world though to a varying degree in each country. A lot of literature and studies are available on this issue but a definite agreement has not been reached on the exact definition and scope of the informal economy. It is also difficult to compile a comprehensive and reliable database on this phenomenon because operations in the informal economy are shrouded in secrecy (Schneider \& Enste, 2000). While diverse views abound about the exact definition, delimitation and measurement of informal activities, Gbanador's (2007) position as cited in Malaolu and Ogbuabor (2013) is used to articulate the diverse views. He asserts that the informal economy is composed of the production and distribution of illegal goods and services and non-reporting of legal economic activities. Braithwaite, Schneider, Reinhart and Murphy (2003), posit that the informal economy constitute a problem to governments worldwide as the higher the percentage of the informal economy to the GDP, the lower the amount of tax revenue accruing to the government. In view of these findings of Braithwaite et al (2003) which is also the position of Schneider \& Enste (2000), it is obvious that Nigeria's tax administration and revenue is seriously encumbered by the shadow economy. Furthermore, Malaolu and Ogbuabor (2013) finds that since 1970, yearly size of the informal economy falls within 53.6 - 77.2\% of GDP which translate to about $64.6 \%$ on the average. The study isolated the extreme case of 2010 when the informal economy was about three-quarter of the GDP. The explanation for the below average performance of income tax in Nigeria can arguably be situated in this abnormally high percentage of the informal sector compared to other countries worldwide and even Africa. According to a Philip Consulting (2014) study, the informal sector in Nigeria is a huge one harbouring about 17 million businesses and enterprises. This is a very significant figure and the implication of such amount of businesses operating informally is critical for government revenue.

\subsubsection{Moderating Role of Public Governance Quality on the Relationship between the Informal Economy and Tax Noncompliance}

There is no divergence of opinion among scholars on the fact that the informal economy is a major problem affecting optimal tax revenue generation. This is unambiguous given that activities of the informal economy are not officially recognised hence cannot be taxed. Thus, the larger the informal economy of a country, the lower the tax revenue it attracts. Given the variations in the sizes of the informal economies across countries worldwide, why would some countries have a smaller informal economy and some, like Nigeria, are burdened with a disproportionately larger informal sector? Could the governments of countries where the informal economy operates be responsible through policy acts of omission or commission?

Ruge (2012) conducted a study on the role of public governance in festering the shadow economy. The study concluded that the quality of public governance, the level of development, effectiveness of public administration and constitutional trust and values are factors in building a formal economy which means deviation from these would foster informality in the economy. Ruge (2012), disagrees with the standard economic view that tax rates is a major determinant that drives people from the formal to the informal economy citing example of Northern European countries where tax rates are high but because of the quality of public governance, the informal economies are smaller. In contrast, Eastern European countries have lower tax rates side by side lower public governance quality and as such have larger shadow economies.

As the study reveals, the size of the shadow economy is inversely correlated with direction of governance quality. Nigeria has one of the largest shadow economies in the world and it is glaring how it also scores among the lowest countries in good governance index. 


\section{Conclusion, Policy Implications and Recommendations}

The study examines the factors responsible for income tax noncompliance in Nigeria. After extensive literature reviews, socio-economic conditions, tax knowledge/education, perceived Audit probability/effectiveness, prevailing social norm, attractiveness of the informal sector and public governance quality were picked based on their suitability for the Nigerian context. Public governance quality was proposed as a moderator, different from what previous researchers have done. After theoretical reviews and synthesis of facts from previous research, it was suggested that public governance quality could be moderating the effect of other factors on abysmal income tax noncompliance situation in Nigeria. Based on the fact that Nigeria's income tax collection is far below world average and also below average in Africa, the study concludes that a strong moderating factor could be at work and given Nigeria's poor record in public governance quality worldwide and Africa, this factor is a possible moderator of the other factors. This conclusion is also supported by the fact that most countries have all the above listed factors that affect income tax noncompliance and yet they collect a higher income tax proportionate to their GDP than Nigeria.

The policy implication of this study is that the Nigerian government and governments of other countries in Nigeria's situation should concentrate on improving governance quality as a precursor of a new tax-led economy. Empirical findings by other studies points to the fact that citizens would reciprocate good governance by paying taxes.

It is recommended that government audits its existing policies to determine their effects on citizens and also seek citizens' participation and inputs in future public policies. Having done that, governments should embark on periodic assessment and reviews of policies and their impacts on the average citizens while strictly enforcing the rule of law and applying it to all citizens equally. These measures will go a long way in creating a new social norm favourable to income tax compliance.

\section{References}

Alabede, J.O (2014). An exploratory analysis of individual taxpayer's behaviour In Nigeria: A study of demographic differences and impact. International Journal of Accounting and Taxation, 2(2)39-64.

Alabede, J.O (2012). An investigation of factors influencing tax payers' Compliance behavior: Evidence from Nigeria. Universiti Utara Malaysia, Unpublished Doctoral Thesis.

Alabede, J.O., Ariffin, Z.Z \& Kamil M.D (2011). Does Ethnicity matter in Individual Tax Payers Behaviour? Empirical Evidence From Nigeria. Economics and Finance Review.1(8) 18-30.

Alesina, A.(1995). Too large and too small governments. Conference on Economic Policy and Equity, Washington DC.

Allingham, M.G\& Sandmo, A.(1972). Income tax evasion, a theoretical analysis. Journal of Public Economics, 1(1972)323 - 338.

Alm, J., Martinez-Vazquez \& Togler, B. (2010) Developing Alternative Frameworks for Explaining Tax Compliance. New York: Routledge.

Anderson, J.E. (2012). Public Finance: Principles and Policies. Masson Ohio: South-Western Cengage Learning.

Ariyo, A. (1997). Productivity of the Nigerian Tax System: 1970 - 1990. Nairobi: African Research Consortium. Research Paper 67.

Aschaeur, D.A(1998). Is public expenditure productive? Journal of Monetary Economics, 23, $177-200$.

Asimiyu, G.A \& Kiziti, E.U. (2014). Analysis of internationally generated revenue and its implication on fiscal viability of state governments in Nigeria Journal of Empirical Economics. 2,(4)216 - 228.

Ayuba, J.A. (2014). Impact of non-oil tax revenue on economic growth: The Nigerian perspective. International Finance and Accounting Journal. 3(5): $303-309$.

Bird, R.M.,(2013). Taxation and development: What have we learned from fifty years of research? Public finance and management. 13 , (4) $266-288$

Bird, R.M; Martinez-Vazques, B \& Torgler, B(2007). Tax effort: The impact of corruption, voice and accountability. Center for Research in Economics, Management and the Arts, Working Paper NO. $2007-13$.

Blank, J.D.(2014). Collateral Compliance. University of Pennsylvania Law Review162, 719.

Blesley, T.\& Torsten, P.(2014). Why do developing countries tax so little. Journal of Economic Perspectives,28(4)99 - 120. DOI:10.1257/jep.28.4.99

Bloomquist, K.(2004).Multi-Agent based simulation of the deterrent effects of tax payers audits. $97^{\text {th }}$ Annual Conference of the National Tax Association.

Brautigam, D.(2002). Building Levithian: Revenue, state capacity and governance. IDS Bulletin, 33(3)

Budina, N. \& Wijnbergen, S.V. (2008). Managing Oil Revenue Volatility in Nigeria: The role of Fiscal Policy. IMF. Afri.427 - 4609 x d.

Buduru, B. \& Pal, L.A(2010). The globalized state: Measuring and monitoring governance. European Journal of Cultural Studies, 13(14)511 - 530. DOI:10.1177/1367549410377144.

Case, K.E. (2008). Musgrave's Vision of the Public Sector: The complex relationship between the individual, society and state in public good theory. Journal of Economics and Finance, 32, 348 - 326.

Cobham, A. (2014). Nigeria's upward revision of GDP should sound alarm on tax- to-GDP ratio.Accessed online@ www.cgdev.org/blog/ 
nigeria-upward-revision-gdp-should-sound alarm-tax-gdp-ratio on 25/01/2015

Cowen, T. \& Tabarrok, A.(2013). Mordern Principles: Macro Economics. New York: Worth Publishers.

Eneji, M.A; Dickson, J.V \& Onabe, B.J.(2013). Health care expenditure, health status and national productivity in Nigeria(1999 - 2012). Journal of Economics and International Finance, 5(\&)258 - 272. DOI: 10.5897/JEL/2013.0523

Fisher, R.C.(1997). The effects of state and local public services on economic development. New England Economic Review, March/April.

Gisselquist, R.M. (2014). Developing and evaluating governance indexes: 10 questions. Policy Studies, 35(5)513 - 531, DOI: $10.1080 / 01442872.2014 .946484$

Helbing, D.; Yu, W.; Opp, K-D. \& Rauhut, H. (2014). Conditions for the emergence of shared norms in populations with incompatible preferences. PLOS ONE, 9(8) $1-15$.

Hofmann, E; Hoelzl, E. \& Kirchler, E.(2008). Knowledge and evaluation of taxation, Norms, fairness and motivation to cooperate. Journal of Psychology, 216(4) 209 - 217. DOI:1027/0044 - 3409.216.4.209

Hulten, C.R. \& Schwab, R.M(1993). Infrastructure spending: Where do we go from here? National Tax Journal, XLVI,3.

IMF. (2011). Revenue mobilization in developing countries. Accessed online @www.imf.org/external/np/pp/eng/2011/030811.pdf Ivanyna, M. \& Haldenwang, C.(2013). Assessing the tax performance of developing Countries German Development Institutefinanced research report.

Jegede, C.A. (2014). Econometric analysis of the effectiveness of public revenue in Economic growth in developing countries: An examination of the Nigerian economy. International Journal of economics and finance, $6(8)$.

Jenkins, G.P; Kuo, C. \& Shukla, G.P(2000). Tax analysis and revenue forecasting - issues and techniques. Harvard Institute for international development, Harvard University. Retrieved from www.jdint.econ.queensu.ca/publications/ged_dp_169.pdf

Kaldor, N.(1963).Will underdeveloped countries learn to tax? Foreign Affairs.

Kott, A.(2012). Assessing whether oil dependency in Venezuela contributes to National instability. Journal of Strategic Security, 5(3) 69 86.

Liman, M. (2009). Causes and consequences of tax evasion in Nigeria. In K.I. Dandago(Ed.). Contemporary Issues in Accounting, Auditing and Taxation.(pp. 186 - 209). Kano: Triump Publishing Company.

Malaolu, V.A \& Ogbuabor, J.E (2013). Size and causes of the informal sector of the Nigerian economy: Evidence from error correction MIMIC Model.Journal of Economics and Sustainable Development, 4(1) 85 - 103.

Martin, S. (2012) Norms, not threat. Ideawatch, Harvard Business Review.

McFerson, H.M(2009). Measuring African governance by attributes or by results? Sage Publications, 25(2)253 - 274. DOI: $10.1177 / 0169796 \times 0902500206$

Michael, O.(2013). Internally generated revenue in Nigeria: A panacea for state Development European Journal of Humanities and Social Sciences,21(1).

Mubiru, A.(2010). Domestic resource mobilization across Africa: Trend, challenges and policy options. African Development Bank. Committee of ten Policy Briefs.

Nwokeji, G.U. (2007). The Nigerian National Petroleum Corporation and The development of the Nigerian oil and gas industry: History, strategies and current directions. Houston: James A. Baker 111 Institute for Public Policy, Rice University.

OECD(2014). OECD Development co-operation peer reviews, United Kingdom, 2014. OECD Publishing. DOI: 10.1787/9789264226579en

Okonjo-Iweala, N. (2014). In my view: Development depends on realizing the potential of taxation. OECD Insights. Retrieved from www.oecdinsights.org/2014/10/09/in-my-view-development-depends-on- realizing-the-potential-of-taxation

Olajide, O.T, Akinlabi, B.H \& Tijani, A.A(2012). Agriculture resource and economic growth in Nigeria. European Scientific Journal, 8.

Olowookere, J.K\& Fasina, H.T(2013). Tax payers education: A key strategy in achieving voluntary compliance in Lagos State, Nigeria. European Journal of Business and Management, 5(10)146 - 154.

Oriakhi, D.E. \& Iyoha, D.O(2013). Oil price volatility and its consequences on the growth of the Nigerian economy: An examination(1970 - 2010). Asian Economic and Financial Review, 3(5):683 - 702.

Oxford (2005). Oxford Dictionary of Accounting. New York: Oxford University Press.

Oyandonghan, K.J \& Igbo, I.E (2013). Motivation and tax compliance in Nigeria: Issues and theories. Journal of Business Management and Administration, 1(1)7 - 14 .

Phillips Consulting(2014). Informal economy survey report, December, 2014. Retrieved from www.phillip consulting.net/en/researchpublication.

Posner, A.P \& Rasmusen, E.B(1999). Creating and enforcing norms, with special reference to sanctions. International Review of Law and Economics, $19,369-382$.

Prasad, N.(2008). Policies for redistribution: The use of tax and social transfers. ILO Discussion Paper Series. DP/194/2008.

Prud'homme, R.(2004). Infrastructure and development. World Bank, Annual Bank Conference on Development Economics.

Pyle, D.J(1991). The economics of taxpayer compliance. Journal of Economic Surveys, 5(2)163 - 198.

Reinert, E.S., (1999). The role of the state in economic growth. Journal of Economic Studies. 26(4/5). 268 - 326.

Ruge, M(2012). Public governance and the shadow economy. German Institute of Economic Research, Shadow Economy Conference.

Saad, N.(2013). Tax knowledge, taxcomplexity and tax compliance: Taxpayers view. Procedia - Social and behavioural sciences, 109(2014)1069- 1075.

Sachs, J.D. \& Warner, M.A. (1997). Natural Resource Abundance and Economic Growth .Harvard Institute for international Development 
and Cambridge Center for International Development.

Sanusi, L. S.(2010). Growth Prospects of the Nigerian Economy. Eight Convocation Lecture. Igbenedion university, Okada. Edo State, Nigeria. Abuja: CBN Research Department.

Schneider, F, \& Enste, D.H (2000). Shadow economies: Size, causes and consequences. Journal of Economic Literature, XXXVIII, 77 114.

Silverman, D.(2005)Doing Qualitative Research. London. Sage publications.

Smith, A. (1776). The wealth of Nations. Pennsylvania State University: Electronic Classic series Publications.

Smith, P. \& Wahba, J. (1995). The role of public finance in economic development: An empirical investigation.

Tanzi, V. (1997). The changing role of the state in the economy: A historical perspective. IMF: Working paper. WP/97/114.

UK House of Commons.(2013). Tax in developing countries: Increasing resource for development.

United Nations. Economic Commission for Africa,(2013) Media Kit.

Volkerink, B.(2009). Tax policy in sub-saharan Africa: A survey of issues for a number of countries. Working paper, Center for Taxation and Governance, Utrecht University.

Wang, S.(2001). The construction of state extractive capacity. Modern China, 27(2) 229 - 261.

Wikipedia. Social Contract. www.wikipedia,org/wiki/social_contract. Accessed on 2/9/2015 